\title{
ANALISIS POSITIONING SMARTPHONE BERDASARKAN PERSEPSI KONSUMEN MAHASISWA FAKULTAS EKONOMI UNIVERSITAS SARJANAWIYATA TAMANSISWA
}

\author{
Finda Mei Murti \\ Suharti \\ Fakultas Ekonomi Universitas Sarjanawiyata Tamansiswa
}

INTISARI

Semakin banyaknya telepon seluler yang ada khususnya smartphone, memberikan banyak pilihan bagi konsumen untuk memilih smartphone seperti apa yang sesuai dengan kebutuhan mereka. Untuk mendapatkan perhatian konsumen suatu perusahaan smartphone perlu mempunyai karakteristik tertentu yang berbeda dengan perusahaan smartphone lainnya atau bisa dikatakan pesaingnya. Memposisikan suatu smartphone diperlukan untuk dapat unggul dalam persaingan. Dalam hal ini smartphone tersebut adalah smartphone Blacberry, smartphone Samsung, dan smartphone Lenovo. Dilihat dari realita dalam gaya hidup dikalangan mahasiswa, khususnya mahasiswa Fakultas Ekonomi Universitas Sarjanawiyata Tamansiswa banyak yang menggunakan dan yang mengetahui smartphone Blackberry, Samsung, dan Lenovo. Maka dari itu penulis mengambil merek smartphone Blackberry, Samsung dan Lenovo untuk diteliti. Tujuan dari penelitian ini adalah untuk mengetahui positioning smartphone berdasarkan persepsi konsumen mahasiswa Fakultas Ekonomi Universitas Sarjanawiyata Tamansiswa. Data yang diperoleh dalam penelitian ini bersifat kualitatif. Untuk teknik pengambilan sampel yang digunakan dalam penelitian ini adalah Purposive Sampling yaitu dengan pertimbangan tertentu. Instrumen penelitian yang digunakan dalam pengumpulan data dalam penelitian ini adalah dengan menggunakan kuesioner yang diisi oleh responden. Sedangkan untuk teknik analisis data yang digunakan adalah analisis Multidimensional scaling (MDS) tiga dimensi.

Hasil penelitian menunjukkan bahwa persepsi konsumen tentang positioning ketiga smartphone memiliki perbedaan dan berada pada posisinya masing-masing dibenak mahasiswa. Dilihat dari atribut desain, fitur dan kualitas smartphone Samsung lebih unggul dibanding smartphone Blackberry dan smartphone Lenovo, hal ini ditunjukkan dalam peta persepsi smartphone Samsung berada di dekat atribut desain, fitur dan kualitas.

Kata kunci: Positioning, Smartphone, Persepsi Konsumen, Multidimensional Scaling (MDS)

\section{PENDAHULUAN}

\subsection{Latar Belakang}

Seiring dengan terus berkembangnya dalam sektor teknologi komunikasi dalam produksi handphone, kini berbagai jenis merek handphone dapat ditemui dengan harga yang semakin terjangkau. Ponsel tidak lagi menjadi barang mewah sehingga kebutuhan ponsel cerdas semakin tinggi. Banyaknya produk handphone yang menawarkan berbagai fasilitasfasilitas lengkap dan menarik, menjadikan masyarakat tertarik untuk membeli dan selalu mengikuti arah perkembangan media teknologi komunikasi yang canggih dengan keluaran handphone terbaru. Tampilan handphone dan fasilitas-fasilitas yang terdapat di dalam handphone, menjadi pertimbangan bagi masyarakat untuk membeli dan memilih handphone yang akan digunakan.

Menurut Publisher Tekonke, smartphone atau ponsel pintar atau lebih familiar dengan sebutan ponsel 
cerdas adalah sebuah perangkat atau produk teknologi berupa telepon genggam atau mobile versi modern terbaru yang memiliki kelebihan dimana spesifikasi software dan hardware lebih pintar, fungsi yang lebih cerdas dan fitur-fitur yang lebih smart dari ponsel versi biasa sebelumnya.

Peran merek menjadi sangat penting karena menjadi pembeda satu produk dengan produk yang lainnya sehingga sangat bergantung pada merek yang ditampilkan. Penciptaan atau pembangunan merek yang tepat memerlukan riset pemasaran yang berkaitan dengan kesesuaian antara merek dengan produk, merek dengan perusahaan, merek dengan nilai-nilai yang ingin disampaikan oleh perusahaan baik nilai produk maupun nilai perusahaan sebagai pemegang merek. Konsumen dalam membeli produk biasanya hanya mengingat yang sudah tertanam di benaknya.

Beberapa merek handphone yang sudah terkenal di Indonesia yaitu Blackberry, Samsung, dan Lenovo sudah melekat sekali dibenak konsumen karena produk tersebut sudah terjamin kualitasnya. Persaingan antar merek dari setiap produk yang semakin tajam, mengakibatkan setiap konsumen dapat memilih variasi merek produk yang lebih berkualitas. Bagi konsumen, kualitas produk sering menjadi perhatian utama. Produk yang dikatakan berkualitas jika seluruh fungsinya dapat dijalankan dengan baik dan bermanfaat. Faktor merek dan harga adalah faktor yang terpenting bagi pengguna layanan mereka di Indonesia ketika memilih sebuah handphone. Rentang harga handphone yang paling sering dicari adalah handphone-handphone yang berharga di bawah 2 juta rupiah.(Telinjuk.com)

Perusahaan yang cerdas akan mencoba memahami sepenuhnya proses pengambilan keputusan pelanggan yaitu semua pengalaman mereka dalam belajar, memilih, menggunakan, bahkan dalam mendisposisikan suatu produk (Kotler, 2007:234). Untuk memenangkan persaingan tidak hanya sebatas menyusun bauran pemasaran sebagai taktik namun lebih dari itu juga menyusun strategi yaitu segmentasi (segmenting), dan target (targeting) pasar yang dituju, serta posisi (positioning) yang diinginkan oleh perusahaan dibenak konsumen. Inti dari setiap strategi pemasaran yang baik adalah suatu strategi pencapaian posisi secara tepat. Istilah positioning mengandung arti bagaimana suatu produk didefinisikan oleh konsumen melalui sifat-sifat pentingnya dibenak konsumen yang dimiliki oleh produk tersebut.

Positioning merupakan hal penting yang dibutuhkan oleh perusahaan, brand, atau produk agar dapat bersaing dengan kompetitornya. Berbagai cara dilakukan oleh perusahaan, brand, atau produk agar dapat menciptakan positioning yang diharapkan di masyarakat. Berdasarkan penjelasan di atas, penulis tertarik untuk menganalisis dan mengkaji mengenai Positioning smartphone berdasarkan persepsi konsumen mahasiswa Fakultas Ekonomi Universitas Sarjanawiyata Tamansiswa.

\subsection{Rumusan Masalah}

Berdasarkan latar belakang di atas, maka rumusan masalah penelitian ini adalah bagaimana peta positioning smartphone berdasarkan persepsi konsumen di kalangan mahasiswa Fakultas Ekonomi Universitas Sarjanawiyata Tamansiswa?

\subsection{Tujuan Penelitian}

Penelitian ini bertujuan untuk mengetahui positioning smartphone berdasarkan persepsi konsumen di kalangan mahasiswa Fakultas Ekonomi Universitas Sarjanawiyata Tamansiswa. 


\section{LANDASAN TEORI}

\subsection{Tinjauan Pustaka}

\subsubsection{Positioning}

Positioning adalah tindakan perusahaan untuk merancang produk dan bauran pemasaran agar dapat tercipta kesan tertentu diingatan konsumen, sehingga dengan demikian konsumen segmen memahami dan menghargai apa yang dilakukan perusahaan dalam kaitannya dengan para pesaingnya. Bila sebuah merek menemukan positioning statement yang efektif, tim merek sering dan sangat bijaksana mempertahankannya dan menggunakannya lagi dan lagi, itulah inti dari positioning statement memosisikan nama merek secara kuat dalam benak orang-orang.

Banyak defenisi positioning diberikan oleh pakar marketing dengan versi dan model mereka masing-masing, namun tak akan valid kita bicara positioning tanpa menyebut defenisi yang diberikan oleh Al-Ries dan Jack Trout, dua orang yang dianggap sebagai penemu positioning. Al-Ries dan Jack Trout (dalam Kartajaya, 2005:56) mengatakan, "positioning is not what you do to a product, positioning is what you do to the mind of the prospect. that is you position the product in the mind of prospect". Intinya positioning adalah menempatkan produk dan merek kita di benak pelanggan. Dengan definisi ini Ries-Trout mengatakan bahwa perang pemasaran bukanlah terletak di pasar, tapi di benak pelanggan. Perang pemasaran adalah perang untuk memperebutkan sejengkal ruang di benak pelanggan.

Menurut Kartajaya (2005:57) positioning adalah "The strategy for leading your consumer credibly" . Positioning adalah menyangkut bagaiman perusahaan membangun kepercayaan, keyakinan, dan trust kepada pelanggan.

Menurut Kotler dan Amstrong (2003:311), positioning adalah cara produk didefinisikan oleh konsumen berdasarkan beberapa atribut penting, tempat yang diduduki produk dalam benak konsumen dibandingkan dengan produk-produk pesaing.

Menurut Kotler (2000:265), terdapat beberapa cara penentuan posisi di benak konsumen, antara lain :

\subsubsection{Penentuan Posisi Menurut Atribut Ini terjadi bila suatu perusahaan mempromosikan atribut produk yang lebih unggul di banding pesaingnya. \\ 2.1.1.2 Penentuan Posisi Menurut Manfaat \\ Dalam pengertian ini produk di posisikan sebagai pemimpin suatu manfaat tertentu. \\ 2.1.1.3 Penentuan Posisi}

Menurut Penggunaan atau Penerapan.

Seperangkat nilai-nilai penggunaan atau penerapan inilah yang digunakan sebagai unsur yang ditonjolkan.

2.1.1.4 Penentuan Posisi Menurut Pemakai

Ini berarti memposisikan produk sebagai yang terbaik untuk sejumlah kelompok pemakai. Dengan kata lain pasar sasaran lebih ditujukan pada satu atau lebih komunitas, baik dalam arti sempit maupun luas. 


\subsubsection{Penentuan Posisi \\ Menurut Pesaing \\ Disini produk secara keseluruhan menonjolkan mereknya secara utuh dan diposisikan lebih baik dari pada pesaing. \\ 2.1.1.6 Penentuan Posisi \\ Menurut Kategori Produk \\ Disini produk diposisikan sebagai pemimpin dalam suatu kategori produk \\ 2.1.1.7 Penentuan Posisi \\ Menurut Harga \\ Disini produk di posisikan memberikan nilai terbaik untuk harganya.}

\subsubsection{Produk}

Salah satu bauran pemasaran yang terpenting adalah produk. Keberadaan produk merupakan penentu bagi program bauran pemasaran yang lain, misalnya penentu harga, program promosi, maupun kegiatan pendistribusiannya. Selain itu produk adalah sesuatu yang esensial yang mampu untuk memenuhi kebutuhan pasar. Produk ditentukan atau dirancang oleh produsen tetapi sebenarnya diproduksi untuk kepentingan pasar juga. Oleh karna itu pengertian produk harus mempertimbangkan pandangan produsen maupun pandang pasar.

Menurut Kotler (2009, p.358) produk (product) adalah apapun yang dapat ditawarkan ke pasar untuk memenuhi kebutuhan dan keinginan, termasuk barang, fisik, layanan, pengalaman, peristiwa, seseorang, tempat properti, organisasi, informasi dan ide. Kotler dan Armstrong (2003: 337) mendefenisikan produk sebagai berikut semua yang dapat ditawarkan kepada pasar untuk diperhatikan, dimiliki, digunakan atau dikonsumsi yang dapat memuaskan keinginan atau kebutuhan pemakainya.

Masing-masing tingkatan produk pada hakekatnya mencerminkan tingkatan kebutuhan konsumen, antara lain:
2.1.2.1 Produk Utama (Core Benefit)

2.1.2.2 Produk Generik (Generik Product)

2.1.2.3 Produk Harapan (Expected Product)

2.1.2.4 Produk (Augmented Product)

2.1.2.5 Produk Potensial (Potential Product)

\subsubsection{Atribut Produk}

Gulitian dan paul (2003,p.69) mendefenisikan atribut, yaitu "atributes represent the spesific features or physical characteristic that are designed into goods or service". Atribut produk merupakan unsur yang dipandang penting oleh konsumen dan dijadikan dasar pengembalian keptusuan pembelian.

Atribut produk terdiri dari merek, kemasan, jaminan (garansi) pelayanan, dan sebagainya. Untuk lebih jelasnya adalah sebagai berikut :

\subsubsection{Merek}

\begin{tabular}{lr}
\multicolumn{1}{c}{ Merek merupakan } \\
nama, istilah tanda, \\
simbol/lambang
\end{tabular} kombinasi atribut-atribut lainnya yang diharapkan dapat memberikan identitas dan differensiasi terhadap produk pesaing. Agar suatu merek dapat mencerminkan makna yang disampaikan, maka ada beberapa persyaratan, yaitu:

2.1.3.1.1 Merek harus khas dan unik. 
2.1.3.1.2 Merek harus dapat menggambarkan manfaat dan kualitas produk.

2.1.3.2 Kemasan

Pengemasan (packaging) adalah suatu proses yang berkaitan dengan perancangan dan pembuatan wadah atau pembungkus untuk suatu produk.

2.1.3.3 Pelayanan

Pada saat ini suatu produk tidak lepas dari unsur jasa sebagai pelengkap.

2.1.3.4 Jaminan (garansi)

Jaminan adalah janji yang merupakan kewajiban produsen atas produknya kepada konsumen, dimana konsumen diberi ganti rugi bila produknya ternyata tidak berfungsi sebagaimana mestinya. Untuk atribut produk sepeda motor yang ditawarkan pada konsumen.

Kotler \&Amstrong (2008) menyatakan ada beberapa atribut yang menyertai dan melengkapi dalam pengembangan suatu produk atau jasa melibatkan pendifinisian manfaat yang akan ditawarkan produk atau jasa. Manfaat ini dikomunikasikan dan dihantarkan oleh atribut produk seperti kualitas, fitur, dan desain.

\subsubsection{Kualitas produk.}

$\begin{array}{lrr} & \text { Kualitas } & \text { adalah } \\ \text { salah satu alat } & \text { penting } \\ \text { bagi pemasar } & \text { untuk } \\ \text { menetapkan } & \text { posisi. }\end{array}$

Kualitas mempunyai dua dimensi, yaitu tingkat dan konsistensi. Ketika mengembangkan suatu produk, pemasar mulamula harus memilih tingkat kualitas yang akan mendukung posisi produk di pasar sasaran. Disini kualitas produk berarti kemampuan produk untuk melaksanakan fungsifungsinya. Selain tingkatan kualitas, kualitas yang tinggi juga dapat berarti konsistensi tingkatan kualitas yang tinggi. Dalam konsistensi tersebut kualitas produk berarti kualitas kesesuaian bebas dari kecacatan dan kekonsistenan dalam memberikan tingkatan kualitas yang dijanjikan.

\subsubsection{Fitur Produk}

Sebuah produk yang ditawarkan dengan berbagai fitur. Sebuah model awal tanpa tambahan yang menyertai produk tersebut menjadi titik awalnya. Perusahaan yang dapat menciptakan model dari tingkat lebih tinggi dengan menambahkan berbagai fitur. Fitur adalah alat persaingan untuk membedakan produk perusahaan terhadap produk sejenis yang menjadi pesaingnya. Menjadi produsen awal yang mengenalkan fitur baru yang dibutuhkan dan dianggap bernilai menjadi salah satu cara yang efektif untuk bersaing.

\subsubsection{Desain}

cara lain untuk menambah nilai bagi pelanggan adalah melalui desain produk yang khas. Desain masuk ke jantung produk, desain yang baik dapat memberikan kontribusi dalam hal kegunaan produk dan juga penampilan. Desain yang baik dapat menarik perhatian, meningkatkan 


$$
\begin{array}{lr}
\text { kinerja } & \text { produk, } \\
\text { memotong } & \text { biaya } \\
\text { produksi, } & \text { dan } \\
\text { memberikan } & \text { keunggulan } \\
\text { bersaing di pasar sasaran. }
\end{array}
$$

\subsubsection{Persepsi Konsumen}

Persepsi merupakan salah satu faktor psikologis selain motivasi pembelajaran dan kepercayaan serta sifat yang dapat mempengaruhi individu dan organisasi dalam menentukan kepuasan pembelian.

Menurut Philip Kotler ( 2005: 216) persepsi adalah :"proses yang digunakan oleh individu untuk memilih, mengorganisasi, dan menginterprestasi masukan informasi guna menciptakan gambaran dunia yang memiliki arti". Menurut Machfoedz (2005, hal. 41) mengemukakan bahwa : "Persepsi adalah proses pemilihan, penyusunan, dan penafsiran informasi untuk mendapatkan arti."

Demikian pentingnya persepsi di benak konsumen, sehingga bermaca-macam strategi di rancang perusahaan supaya produk dan mereknya bisa menjadi nomor satu di benak konsumen.

\subsubsection{Pembentukan Persepsi}

Terdapat Tiga tahap dalam pembentukan persepsi customer, yaitu : Tahap 1 : Sensasi

Sensasi
adalah suatu
proses penyerapan
informasi
mengenai suatu
produk yang
melibatkan panca
indra customer
(pendengaran,
penglihatan,
penciuman dan
peraba).

Tahap 2 : Organisasi

\begin{tabular}{lr}
\multicolumn{2}{c}{ Organsiasi } \\
adalah $r$ tahap \\
dimana customer \\
mengolah \\
informasi yang \\
telah ia dapatkan \\
pada rahap \\
sensasi.
\end{tabular}

Tahap 3 : Interpretasi

$$
\begin{array}{lr}
\text { Interpretas } \\
\text { i r adalah } \\
\text { pengambilan citra } \\
\text { atau pemberian } \\
\text { makna roleh } \\
\text { customer terhadap } \\
\text { suatu produk. }
\end{array}
$$

\subsubsection{Penegertian Perceptual Mapping}

Peta persepsi dapat terjadi karena adanya pandangan konsumen dalam menilai suatu merek sehingga kemudian mempercayai merek tersebut. Menurut Ratnawati (2002.p.37)““ pemetaan persepsi (perception mapping) menunjukkan tempat dimana konsumen lebih suka menempatkan produk sesuai dengan yang mereka rasakan “. Dengan peta persepsi, tiap-tiap merek atau produk menempati (titik) khusus. Produk atau merek yang memiliki kesamaan akan saling berdekatan, sedangkan yang memiliki banyak perbedaan akan berjauhan.

\section{METODOLOGI PENELITIAN \\ 3.1 Sifat Penelitian}

Penelitian ini menggunakan pendekatan kuantitatif deskriptif karena data yang diambil menggunakan angka, mulai dari pengumpulan data, penafsiran terhadap data tersebut, serta penampilan dari hasilnya (Rosady Ruslan, 2003: 81).

Menurut Jonathan Sarwonno (2006) "metode penelitian kuantitatif adalah penelitian ilmiah yang sistematis terhadap bagian-bagian dan fenomena 
serta hubungan-hubungannya", dengan cara deskriptif dalam bentuk kata-kata dan bahasa, dengan memanfaatkan beberapa metode alamiah. Metode Penelitian Kuantitatif, sebagaimana dikemukakan oleh Sugiyono (2009:14) dapat diartikan sebagai metode penelitian yang berlandaskan pada filsafat positivisme, digunakan untuk meneliti pada populasi atau sampel tertentu.

\subsection{Variabel Penelitian}

Menurut Sugiyono (2003:31) definisi dari variabel adalah "segala sesuatu hal yang berbentuk apa saja yang ditetapkan oleh peneliti untuk dipelajari sehingga diperoleh informasi tentang hal tersebut, kemudian ditarik kesimpulannya".

Dalam penelitian ini variabel yang diketahui, yaitu positioning menurut atribut berdasarkan persepsi konsumen yang dilihat dari tiga atribut desain, fitur, dan kualitas.

\subsection{Definisi Operasional}

\subsubsection{Positioning}

Yang dimaksud dengan positioning merancang produk dan bauran pemasaran agar dapat tercipta kesan tertentu diingatan atau dibenak konsumen. Sehingga menempati posisi yang khas diantara pesaing di dalam benak pelanggan sasarannya.

3.3.2 Desain

Desain merupakan tampilan luar yang melekat dan memberikan ciri pada produk itu sehingga konsumen mampu membedakan produk yang satu dengan yang lain serta daya tarik bagi konsumen.

\subsubsection{Fitur}

Fiture sebagai karakter spesifik yang melekat pada produk. Fitur yang biasa dikenal dengan aplikasi ini seperti facebook, twitter, GPS, browser, dan lainnya.

\subsubsection{Kualitas}

kualitas yaitu kemampuan produk smartphone Blackberry, Samsung, dan Lenovo untuk menjalankan tugasnya yang mencakup kehandalan atau kemajuan, kekuatan, dan ciri-ciri lainnya.

\subsection{Populasi daan Sampel}

Populasi adalah wilayah generalisasi yang terdiri atas: obyek/subyek yang mempunyai kualitas dan karakteristik tertentu yang ditetapkan oleh peneliti untuk dipelajari dan kemudian ditarik kesimpulannya Sugiyono (2011: 61). Populasi dalam penelitian ini adalah mahasiswa dan mahasiswi Fakultas Ekonomi Universitas Sarjanawiyata Tamansiswa yang mengetahui smartphone Blackberry, Samsung dan Lenovo.

Sampel adalah bagian dari populasi yang karakteristiknya hendak diteliti. Sampel adalah "himpunan bagian dari unit populasi" (Kuncoro, 2003 : 103). Sampel dari penelitian ini adalah Mahasiswa Fakultas Ekonomi Universitas Sarjanawiyata Tamansiswa yang mengetahui smartphone Blackberry, Samsung, dan Lenovo..

Jumlah sampel dalam penelitian ini ditetapkan sebanyak 50 sampel, yang dipandang sudah memadai untuk diolah. Hal ini karena jumlah populasiya tidak diketahui, maka jumlah sampel minimal adalah 30 orang (Arikunto Suharsini, 2006 : 125).

Roscoe dalam buku Research Methods For Business (1982:253) memberikan saran-saran tentang ukuran sampel untuk penelitian seperti berikut :

3.4.1 Ukuran yang layak dalam
penelitian adalah antara 30
3ampai dengan 500.
Bila sampel dibagi dalam
kategori (misalnya : pria-
wanita, pendapatan, pegawai
penelitian adalah antara 30 Bila sampel dibagi dalam wanita, pendapatan, pegawai 
negeri-swasta dan lain-lain) maka jumlah anggota sampel setiap kategori minimal 30.

Teknik penarikan sample yang digunakan adalah Purposive Sampling adalah teknik penentuan sampel dengan pertimbangan tertentu. Pertimbangan yang dimaksud yaitu mahasiswa mahasiswi yang mengetahui smartphone Blackberry, Samsung dan Lenovo.

3.5 Sumber Data dan metode pengumpulan data

Sumber data yang digunakan dalam penelitian ini adalah data primer. Pelaksanaan pengumpulan data penelitian ini dilakukan dengan metode Kuesioner. Kuesioner adalah sejumlah pertanyaan secara tertulis yang akan dijawab oleh responden peneliti, dengan tujuan memperoleh data lapangan atau empiris untuk memecahkan masalah peneliti dan mendapat tanggapan dari responden yang disampel.

\subsection{Teknik Analisis Data}

\subsubsection{Uji Validitas dan Uji Reliabilitas}

Validitas menunjukan sejauh mana suatu talat pengukur dapat mengukur apa yang ingin diukur.

Kriteria yang digunakan untuk menyatakan suatu instrumen dianggap valid atau layak digunakan dalam pengujian apabila koefisien korelasi lebih besar atau sama dengan 0,30 (Azwar dalam Duwi , 2011). Dilakuan dengan membandingkan nilai $r$ hitung dengan $r$ tabel untuk tingkat signifikansi 5 persen dari degree of freedom $(\mathrm{df})=\mathrm{n}-2$, dalam hal ini $\mathrm{n}$ adalah jumlah sampel. Jika $r$ hitung $>r$ tabel maka pertanyaan atau indikator tersebut dinyatakan valid, demikian sebaliknya bila $r$ hitung $<\mathrm{r}$ tabel maka pertanyaan atau indikator tersebut dinyatakan tidak valid (Ghozali, 2005).

Reliabilitas adalah suatu nilai yang menunjukan konsistensi suatu alat pengukur didalam mengukur gejala yang sama. Makin kecil kesalahan pengukuran, makin reliable alat pengukur. Sebaliknya makin besar kesalahan pengukuran, makin tidak reliable alat pengukur tersebut.

Suatu variabel dikatakan reliabel jika memberikan nilai $\alpha$ $>$ 0,60 (Nunnally, 1967 dalam Ghozali, 2005: 42). Untuk menguji reliabilitas butir adalah sebagai berikut :

1. Jika $\alpha>0,60$ atau $60 \%$, maka butir atau variabel tersebut reliabel.

2. Jika $\alpha<0,60$ atau $60 \%$, maka butir atau variabel tersebut tidak reliabel.

Dalam tahap pengelolaan data, jumlah diganti dengan angka satu sampai lima agar dapat dijumlahkan. Dalam penghitungan scoring digunakan skala Likert yang pengukurannya sebagai berikut ( Sugiyono, $2004: 87$ ) :

1) Skor 5 untuk jawaban sangat setuju

2) Skor 4 untuk jawaban setuju

3) Skor 3 untuk jawaban netral

4) Skor 2 untuk jawaban tidak setuju

5) Skor 1 untuk jawaban sangat tidak setuju

\subsection{Analisis Multidimensional Scaling (MDS)}

Teknik analisis data yang digunakan dalam penelitian ini adalah menggunakan teknik analisis multidimensional scaling. Analisis Multidimensional Scaling yaitu suatu prosedur yang digunakan untuk menggambarkan persepsi dalam sebuah display. Tujuan dari multidimensional scaling (MDS) adalah untuk memberikan 
gambaran visual dari pola kedekatan yang berupa kesamaan atau jarak diantara sekumpulan objek-objek. MDS sangat popular dalam penelitian bidang pemasaran untuk perbandingan brand.

Dalam aplikasi peneltian multidimensional scaling (MDS) sering digunakan untuk memetakan persepsi konsumen terhadap suatu objek dengan menggunakan tiga dimensi. Dari hasil pemetaan ini akan diperoleh posisi persaingannya yang akan dipersepsikan oleh konsumen. Pasangan objek terdekat dianggap memiliki banyak kemiringan, sedangkan pasangan terjauh memiliki banyak perbedaan.

\section{HASIL DAN PEMBAHASAN}

Setelah diketahui dari setiap atribut dan indikator dalam hasil kuesioner, dapat dihasilkan sebuah peta yang menyatakan bahwa kebanyakan mahasiswa dan mahasiswi Fakultas Ekonomi Universitas Sarjanawiyata Tamansiswa memposisikan ketiga atribut yaitu desain, fitur dan kualitas, terletak saling berdekatan antara fitur dan kualitas, sedangkan desain letaknya berada jauh dengan kedua atribut tersebut. Ini diartikan bahwa dibenak mahasiswa dan mahasiswi atribut fitur selalu berkaitan dengan kualitas ataupun sebaliknya, dan menomor duakan atribut desain. Namun ada pula mahasiswa dan mahasiswi yang mengutamakan desain dari pada kualitas dan fitur.

Sedangkan jika dilihat dari ketiga smartphone Blackberry, Samsung dan Lenovo, mahasiswa dan mahasiswi memposisikan ketiga smartphone tersebut memiliki dan terletak diposisinya masing-masing, karena letak ketiga smartphone saling berjauhan. Ini dapat dipersepsikan bahwa ketiga smartphone tersebut memiliki posisinya masing-masing dibenak konsumen.

Secara keseluruhan jika dilihat dari atribut dan produk maka Samsung diposisikan memiliki desain, kualitas dan fitur, namun Samsung diposisikan lebih ke desain karena letaknya yang saling berdekatan. Sedangkan Kualitas dan fitur letaknya jauh dengan Samsung. Meski demikian smartphone Samsung lebih unggul daripada smartphone Blackberry, dan Lenovo jika dilihat dari atribut desain, kualitas dan fitur.

Untuk smartphone Lenovo diposisikan memiliki fitur, kualitas, dan desain, namun letak ketiga atribut tersebut berada jauh dari Lenovo. Jika diartikan Lenovo memiliki fitur dan kualitas yang bagus tetapi untuk desain Lenovo hanya biasa saja dan kurang menarik menurut konsumen. Sedangkan untuk smartphone Blackberry diposisikan berada sangat jauh dari ketiga atribut yaitu desain, kualitas dan fitur. Bukan berarti smartphone Blackberry diposisikan tidak memiliki ketiga atribut tersebut melainkan smartphone Blackberry tidak terfikirkan oleh mahasiswa jika dilihat dari ketiga atribut tersebut, karena smartphone Blackberry kurang memberikan daya tarik dari ketiga atribut desain, kualitas dan fitur berdasarkan persepsi mahasiswa.

\section{KESIMPULAN}

Jadi secara keseluruhan jika dilihat dari atribut dan produk maka Samsung diposisikan smartphone yang unggul dari pada smartphone Blackberry dan Lenovo. Karena smartphone Samsung memiliki desain, kualitas dan fitur, namun Samsung diposisikan lebih ke desain karena letaknya yang saling berdekatan. Sedangkan Kualitas dan fitur letaknya jauh dengan Samsung. Untuk smartphone Lenovo diposisikan memiliki fitur, kualitas, dan desain, namun letak ketiga atribut tersebut berada jauh dari Lenovo. Jika diartikan Lenovo memiliki fitur dan kualitas yang bagus tetapi untuk desain Lenovo hanya biasa saja dan kurang menarik menurut konsumen.

Sedangkan untuk smartphone Blackberry diposisikan berada sangat jauh dari ketiga atribut yaitu desain, kualitas dan 
fitur. Bukan berarti smartphone Blackberry diposisikan tidak memiliki ketiga atribut tersebut melainkan smartphone Blackberry tidak terfikirkan oleh mahasiswa jika dilihat dari ketiga atribut tersebut, karena smartphone Blackberry kurang memberikan daya tarik dari ketiga atribut desain, kualitas dan fitur berdasarkan persepsi mahasiswa.

\section{REFERENSI}

Anggoro, M. Toha et.al. 2007. Metode Penelitian. Jakarta: Universitas Terbuka

Borg, I. dan Groenen, P.J.F. 2005. Modern Multidimensional Scaling Theory and Application. New York: Springer

Churchill, Gilbert.A. 2002. Dasar-dasar Riset Pemasaran Jilid 1. Jakarta: Erlangga

Effendi, Sofian et..al. 2012. Metode Penelitian Survei. Jakarta: LP3ES

Ghozali, Imam. 2006. Aplikasi Analisis Multivariate dengan Program SPSS. Semarang: Universitas Diponegoro

Malhotra, Noresh. K. 2006. Riset Pemasaran Pendekatan Terapan. Jakarta: PT Indeks Kelompok Gramedia

Nasir, Moh. 1988. Metode Penelitian. Jakarta: Ghalia Indonesia.

Santoso, Singgih et.al. 2001. Riset Pemasaran Konsep dan Aplikasi dengan SPSS. Jakarta: PT Elex Media Komputindo

Simamora, Bilson. 2005. Analisis Multivariat Pemasaran. Jakarta: PT Gramedia

Sugiyono. 2009. Metode Penelitian Bisnis (Pendekatan kuantitatif, kualitatif dan $R \& D)$. Bandung: Alfabeta

Suharsimi Arikunto. 2010. Prosedur Penelitian Suatu Pendekatan Praktik. Jakarta: Rineka Cipta

Supranto. 2004. Analisis Multivariat Arti dan Interprestasi. Jakarta: RINEKA CIPTA

Winarno Surakhmad. 1998. Pengantar Penelitian Ilmiah: Dasar, Metode, Teknik. Bandung: Tarsito http://sejarah-bb.blogspot.com/ diakses pada tanggal 4 April 2014 pukul 23.15 WIB

http//www.google.com. "blackberry, data, handphone, samsung, Telunjuk.com" diakses pada tanggal 4 April 2014 pukul 2320 WIB

http//www.google.com. " statistik 4 life, Multidimensinal Scaling”. Diakses pada tanggal 3 April 2014 pukul 21.00 WIB

http://id.wikipedia.org/wiki/Lenovo. diakses pada tanggal 4 April 2014 pukul 23.00 WIB

http://www.scribd.com/doc/114706275/Mult idimensional-Scaling-Analysis. diakses pada tanggal 5 April 2014 pukul 13:00 WIB

http://bonteng.wordpress.com/2009/11/16/at ribut-produk/ diakses pada tanggal 1 April 2014 pukul 13:25 WIB 